\title{
An Unusual Anatomical Variation of the Levator Scapulae Muscle
}

\author{
Una Variación Anatómica Inusual del Músculo Elevador de la Escápula \\ "Gabriel Varjão Lima; ${ }^{* *, * * *, * * * *}$ Richard Halti Cabral; "Danilo Leite Andrade; \\ ******* Nayara Soares de Oliveira Lacerda; "Vital Fernandes Araújo \& *******Telma Sumie Masuko
}

VARJÂO, L. G.; CABRAL, H. R.; ANDRADE, D. L.; LACERDA, N. S. O.; ARAÚJO, V. F. \& MASUKO, T. S. An unusual anatomical variation of the levator scapulae muscle. Int. J. Morphol., 30(3):866-869, 2012.

SUMMARY: Clinical and surgical importance of the levator scapulae muscle (LSM) requires a better knowledge of its anatomic variation mainly because of the possibility of new findings related to the embryologic development. This article reports a case of a leftsided LSM with atypical attachments in a 58-year-old preserved Caucasian female body. The muscle presented a bifurcation at its midpoint downward path. Its medial band attached to the anterior aspect of the left rhomboideus major muscle while its left band was fixed in the superior angle of the scapula after releasing a muscle expansion to the serratus anterior muscle. The morphometric analysis revealed LSM maximal width of $3.6 \mathrm{~cm}$, bifurcation point located $6.6 \mathrm{~cm}$ apart from the $\mathrm{C} 1$ vertebral attachment; medial band legth of $5.7 \mathrm{~cm}$ and lateral band width of $2.1 \mathrm{~cm}$. Regarding anatomic variations of the LSM, they may remain unnoticed or perhaps contribute for pathologic conditions of the neck and the back.

KEY WORDS: Levator scapulae muscle; Anatomical variation; Macroscopic anatomy; Clinical anatomy; Muscular system.

\section{INTRODUCTION}

The levator scapulae muscle (LSM) is a triangular band-like muscle situated in lateral cervical region (posterior triangle of neck), deep to the sternocleidomastoid and trapezius muscles. It has been described as arising on the transverse processes of the first four cervical vertebrae and its attachment on medial border of the scapula, between the superior angle and the triangular smooth surface at the root of its spine (Testut \& Latarjet, 1979). In addition, it may have tendinous expansions to the temporal and occipital bones, to rhomboid major, trapezius, serratus anterior and serratus posterior superior muscles (Williams et al., 1995).

The LSM elevates and assists in the retraction and aduction of the scapula. With the scapula fixed, it inclines the neck sidelong and rotates it lightly to the same side when acting unilaterally, and extends the neck when acting bilaterally.

The knowledge of this muscle is important in head and neck reconstructive surgeries (Marks \& Cummings, 1985), once the LSM has strategic topographic location, considerable length, rich vascularization and motor nervous points relatively constant (Mardones \& Rodríguez, 2006a; Mardones \& Rodríguez, 2006b).

We present a case of anatomic variation in which the left levator scapulae muscle has extra superior attachments and two distal bifurcations.

\section{CASE REPORT}

A left-sided LSM with atypical attachments was found during dissection of a 58-year-old preserved Caucasian female body (Fig. 1). The embalming process was based on the technique of Baptista et al. (1986). This muscle had the usual superior attachment in the spinous processes of the first four cervical vertebrae. At the midpoint of its downward trajectory, the muscle divided itself in two different bands. The medial band directed itself to the anterior aspect of the left rhomboideus

* Graduate Student - Faculty of Medicine of the Federal University of Bahia (FMB-UFBA), Brazil.

** Associate Professor, Department of Anatomy, Institute of Biomedical Sciences, University of São Paulo (ICB-USP), Brazil.

*** Discipline of Surgical Technique and Experimental Surgery, Department of Surgery, University of São Paulo Medical School (FMUSP), Brazil.

***** Full Professor, Discipline of Applied Human Anatomy, Metropolitan University of Santos (UNIMES), Brazil.

****** Graduate Student, Bahiana School of Medicine and Public Health (EBMSP), Brazil.

******* Associate Professor, Department of Biomorphology, Institute of Health Sciences, Bahia Federal University (ICS-UFBA), Brazil. 
major muscle at the level of the second thoracic vertebra. The left band directed itself to the superior angle of the scapula and before its fixation to the bone it released a muscle expansion to the aponeurosis of the serratus anterior muscle.

The morphometric analysis revealed:
- LSM maximal width - $3.6 \mathrm{~cm}$, measured just before its bifurcation;

- Bifurcation point - located $6.6 \mathrm{~cm}$ apart from the $\mathrm{C} 1$ vertebral attachment;

- Medial band: $5.7 \mathrm{~cm}$ of length and $0.8 \mathrm{~cm}$ of width; - Lateral band: $6.5 \mathrm{~cm}$ of length and $2.1 \mathrm{~cm}$ of width.
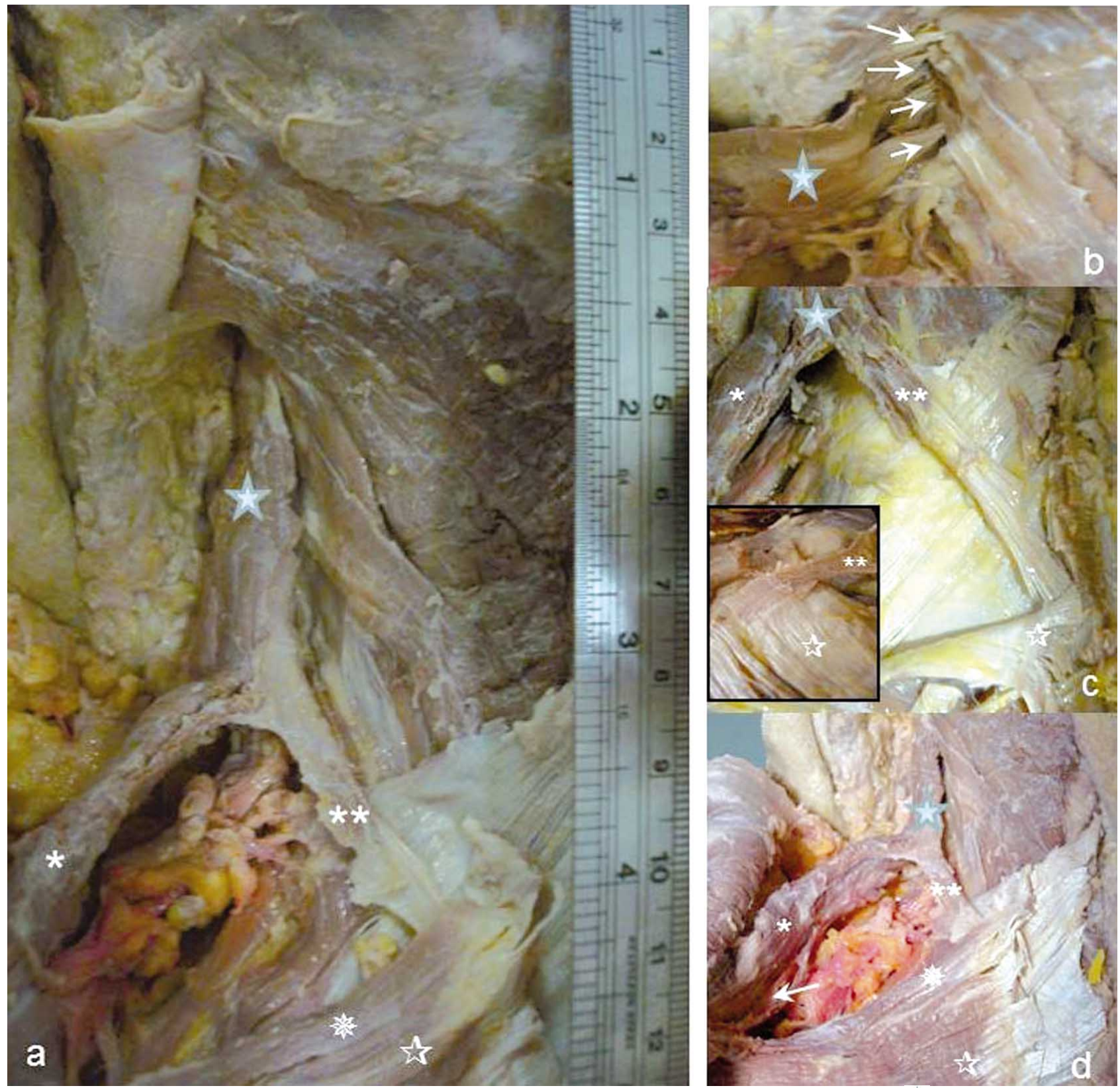

Fig. 1. Left-sided LSM with atypical attachments. (a) Note the upper segment of the muscle ( $\hbar$ ) and its bifurcation originating a lateral band $(*)$ and a medial band $(* *)$ running in the direction of the rhomboideus major ( $\vec{*})$ and minor muscles $\left(\frac{\hbar}{k}\right)$. (b) Detail of the superior attachments $\left(\Rightarrow\right.$ ) of the upper segment of the LSM $\left(\frac{1}{\zeta}\right)$. (c) The medial band (**) running down to the anterior aspect of the left rhomboideus major muscle $(\dot{\psi})$ at the level of the second thoracic vertebra. Note detail in the inlet picture, in which the left rhomboideus major muscle ( $\vec{\forall}$ ) was folded to enable visualization of the insertion of the medial band $(* *)$. (d) The left band $(*)$ releasing a muscle expansion $\Leftrightarrow)$ to the aponeurosis of the serratus anterior muscle. 


\section{DISCUSSION}

The report of anatomic variations seems to be important for medical literature in order to clarify controversial or unknown clinical presentations and also to improve anatomical knowledge.

LSM is an important component of the medial girdle muscles of the upper limb which has important contributions for the movement of the scapula and the neck. Its embryological origin comes from the axial somites, together with the axial skeleton but differently from the forelimb muscles, which develop by cell migration from the somites under Met signaling (Valasek et al., 2010). LSM together with serratus anterior, rhomboideus major and minor muscles are classified as hypaxial muscles, have their attachments in the medial border of the scapula and have the same embryologic origin. This is also confirmed by their innervation which is made by the cervical spinal nerves.

Regarding anatomic variations of the LSM they may remain unnoticed or perhaps contribute for pathologic conditions of the neck and the back. The most common variations of the LSM refer to its insertion points: superior attachments to the transverse processes of cervical vertebrae $\mathrm{C} 5, \mathrm{C} 6$ and $\mathrm{C} 7$; fixation in the temporal and occipital bones; inferior attachments to the first ten ribs, to the aponeurosis of serratus posterior superior and to serratus anterior muscles (Testut \& Latarjet).

Loukas et al., (2006) described a case whose LSM presented a high division of its belly, generating what he called accessory head (medial band) which was inserted in the tendon of rhomboid major muscle, in the nuchal ligament and in the serratus posterior superior muscle by an aponeurotic band.

In the case reported in this article, LSM features like the division point location and the pattern of muscle bands and expansions seemed to be somehow different from other presented anatomic variations. This fact not only brings scientific importance due to the possible rarity of the presented anatomy but also for its clinical implications in surgical procedures (LSM translocation, LSM surgical flap, head and neck surgery) and clinical manifestations.

LSM location may propiciate the development of myofascial syndrome, characterized by the presence of triggers points due to excessive use of muscle groups, local traumatism and presence of anatomic variations (Lee et al., 2008). Moreover, abnormal contraction of the LSM may represent an important triggering factor for laterocollic cervical dystonia, characterized by abnormal positioning of the head (Taira et al., 2003). In cases of radical neck dissection, LSM can be used to protect the carotid artery (Schweitzer, 1962).

In conclusion, clinical and surgical importance of the levator scapulae muscle requires a better knowledge of its anatomic variation mainly because of the possibility of new findings related to the embryologic development, as presented in this paper.

VARJÂO, L. G.; CABRAL, H. R.; ANDRADE, D. L.; LACERDA, N. S. O.; ARAÚJO, V. F. \& MASUKO, T. S. Una variación anatómica inusual del músculo elevador de la escápula. Int. J. Morphol., 30(3):866-869, 2012.

RESUMEN: Debido a la importancia clínica y quirúrgica del músculo elevador de la escápula, se hace necesario conocer mejor sus variaciones, principalmente la posibilidad de encontrar hallazgos relacionados con su desarrollo embriológico. Se presenta el caso de un músculo elevador de la escápula del lado izquierdo encontrado en un cadáver de sexo femenino de 58 años. El músculo elevador de la escáula presentaba una bifurcación en el punto medio en su trayectoria más baja. La banda medial se fijaba en la parte anterior del músculo romboides mayor izquierdo; mientras que su banda lateral se fijaba en el ángulo superior de la escápula después de enviar una expansión hasta el músculo serrato anterior. El análisis morfométrico reveló un ancho máximo de 3,6 cm, punto de bifurcación situado $6,6 \mathrm{~cm}$ bajo la inserción vertebral $\mathrm{C} 1$; longitudes de la banda medial $5,7 \mathrm{~cm}$ y lateral de $2,1 \mathrm{~cm}$. Las variaciones anatómicas del músculo elevador de la escápula pueden pasar inadvertidas, pero también pueden contribuir con algunas condiciones patológicas del cuello y espalda.

PALABRAS CLAVE: Músculo elevador de la escápula; Variación anatómica; Anatomía clínica; Sistema muscular.

\section{REFERENCES}

Baptista, C. A. C.; Cerqueira, E. P.; Silva, J.T. \& Mansfield, J. K.

Conservation and dry storage of cadavers through the vacuum for anatomical studies. Rev. Bras. Cienc. Morf., 3:121-3, 1986. 
VARJÂO, L. G.; CABRAL, H. R.; ANDRADE, D. L.; LACERDA, N. S. O.; ARAÚJO, V. F. \& MASUKO, T. S. An unusual anatomical variation of the levator scapulae muscle. Int. J. Morphol., 30(3):866-869, 2012.

Lee, S. H.; Chen, C. C.; Lee, C. S.; Lin, T. C. \& Chan, R. C. Effects of needle electrical intramuscular stimulation on shoulder and cervical myofascial pain syndrome and microcirculation. $J$. Chin. Med. Assoc., 71(4):200-6, 2008.

Loukas, M.; Louis, R. G. Jr. \& Merbs, W. A case of atypical insertion of the levator scapulae. Folia Morphol. (Warsz), 65(3):232-5, 2006.

Mardones, V. F. \& Rodríguez, T. A. Levator scapulae muscle: blood supply and innervation. Int. J. Morphol., 24(3):363-8, 2006 .

Mardones, V. F. \& Rodríguez, T. A. Levator scapulae muscle: macroscopic characterization. Int. J. Morphol., 24(2):251-8, 2006b.

Marks, N. J. \& Cummings, C. W. The levator scapulae muscle flap. A new use. J. Laryngol. Otol., 99(5):471-4, 1985.

Schweitzer, R. J. Use of muscle flaps for protection of carotid artery after radical neck dissection. Ann. Surg., 156:811-8, 1962.

Taira, T.; Kobayashi, T. \& Hori, T. Selective peripheral denervation of the levator scapulae muscle for laterocollic cervical dystonia. J. Clin. Neurosci., 10(4):449-52, 2003.

Testut, L. \& Latarjet, A. Anatomía humana. 9ª Ed. Barcelona, Salvat, 1979.

Valasek, P.; Theis, S.; Krejci, E.; Grim, M.; Maina, F.; Shwartz, Y.; Otto, A.; Huang, R. \& Patel, K. Somitic origin of the medial border of the mammalian scapula and its homology to the avian scapula blade. J. Anat., 216(4):482-8, 2010.

Williams, P. L.; Bannister, L. H.; Berry, M. M.; Collins, P.; Dussek, J. E. \& Ferguson, M. W. J. Gray Anatomia. Rio de Janeiro, Guanabara Koogan, 1995.
Correspondence to:

Dra. Telma Sumie Masuko

Universidade Federal da Bahia

Instituto de Clências da Saúde

Dep. Biomorfologia

Av. Reitor Miguel Calmon, s/n $\mathrm{n}^{\circ}$

Vale do Canela

40160-100

Salvador, Bahia

BRAZIL

Email: tsmasuko@uol.com.br tsmasuko@gmail.com

Received: 26-09-2011

Accepted: 03-04-2012 